\title{
Soil and Climatic Influence on the Free and Glycosidically Bound Volatiles of Grapes from Two White Varieties from Vinhos Verdes Region
}

\author{
M. Araújo, J.M. Oliveira and M.O. Maia \\ Centro de Engenharia Biológica, \\ Universidade do Minho, Campus de \\ Gualtar, 4710-057 Braga \\ Portugal
}

\author{
R.L. Baumes \\ Unité Mixte de Recherches Sciences pour \\ L'Enologie, INRA - M, 2 Place Viala, \\ 36060 Montpellier Cedex 01 \\ France
}

Keywords: Alvarinho, Loureiro, varietal aroma, bioclimatic indexes, volatile compounds

\begin{abstract}
The Vinhos Verdes Region is situated in the northwest of Portugal. The Atlantic Ocean and the relief markedly influence the climate. This region is in Viticultural Zone C I a) of the Winegrowing Regions of the European Communities. The produced wine is unique and its specific characteristics are mainly due to the climate and soil. The white Vinho Verde is softly alcoholic, with a delicate, fresh and fruity bouquet. In this work we investigated the influence of the climate and the soil on the volatile compounds of grapes from two autochthonous white grape varieties, Alvarinho and Loureiro, in two sub-regions for each one of them (Alvarinho Monção and Lima; Loureiro - Lima and Cávado). The research was carried out during three years: 1996, 1997 and 1998. We found out that the global characteristics of the grapes from the two varieties depend on the harvest factor (climate) rather than on the sub-region where the vine is planted. The characteristics of the soil have an even lesser influence on the variableness of the samples, although the Alvarinho variety picked in the Lima sub-region seems to have different characteristics.
\end{abstract}

\section{INTRODUCTION}

The Vinhos Verdes Region, situated in the north of Portugal, is surrounded by the following geographical features: the river Minho in the north, the river Douro in the south, the Atlantic Ocean in the west and mountain relief in the east (Peneda, Gerês, Cabreira and Marão). Since the climate of this Region is markedly influenced by the Atlantic Ocean, it presents mild air temperatures and thermal ranges, high average rainfall and poor solar radiation. The local soils are mostly of granitic origin, and therefore with a more or less sandy, franc or franc-sandy texture (Pinho, 1993). These environmental conditions are a contribution to the production of a regional wine with special characteristics, namely soft alcohol grade and high fixed acidity, the Vinho Verde. The climate and the soil have a fundamental role in the development of the grapevine, influencing the quality of the grapes and hence of the wine itself. Besides the possibility of limiting or even restricting the establishment of the culture, these abiotic factors are responsible for a great diversity of situations (Clímaco, 1997). There are several bioclimatic indexes, which are numerical indications that are used in most cases to characterize the climate potentials of a given "terroir" (Huglin and Schneider, 1998). They all integrate the temperature factor.

The aroma is intrinsically connected to the quality of the wines. We can distinguish four types of aroma according to their origin: varietal, pre-fermentative, fermentative and post-fermentative. The former one characterize the cultivar and depends on the grape variety, climate, soil and phytotechny (Cordonnier and Bayonove, 1978). It is present at as free form and as glycosilated bound form.

Among the white grape varieties recommended for the Vinhos Verdes Region, Alvarinho and Loureiro produce high quality wines. This work aimed to investigate the influence of climate and soil on the volatile compounds expression of these two grape 
varieties.

\section{MATERIALS AND METHODS}

The grapes from the two white grape varieties, Alvarinho and Loureiro, were picked at three successive harvests (1996, 1997 and 1998) in different sample sites in the Vinhos Verdes Region; the codes of the samples are shown in table 1. The soils have a granitic origin, with an average texture except for one of the soils of Monção $\left(\mathrm{A}_{\mathrm{CR}}\right)$ which is covered by different-sized pebbles down to about $80 \mathrm{~cm}$ depth. A summary of the characteristics of the soils of the sample sites is to be found in table 2 .

Volatile compounds were quantified through the method referred by Günata et al. (1985) and adapted by Oliveira (2000a) and Oliveira et al. (2000b). Bioclimatic indexes were determined for each year and for each sub-region in order to find the respective characterizations; according to Huglin and Schneider (1998), the following were determined: Amerine, Heliotermic of Huglin, Hidrotermic of Selianov and Hidrotermic of Branas, Vernon and Levadoux.

A statistic processing was made through Principal Component Analysis and the program SPSS 10.0 was used.

\section{Results and Discussion}

The calculated bioclimatic indexes (table 3), which only take into account the temperature factor, indicate that the years 1997 and 1998 were better than the year 1996. Concerning the indicator of Winkler and Amerine, which defines the types of wine producing regions according to the thermal characteristics of their climate (Huglin and Schneider, 1998), it situates the Monção sub-region in the years 1997 and 1998 in zone 4 $\left(1951^{\circ} \mathrm{C}-2220^{\circ} \mathrm{C}\right)$ and in zone $3\left(1671^{\circ} \mathrm{C}-1950{ }^{\circ} \mathrm{C}\right)$ the Lima sub-region in the three years and the Monção sub-region in the year 1996. The Heliothermic Index of Huglin presents higher values for the years of 1997 and 1998. The other two calculated indexes, in which the average rainfall is taken into account, indicate that the years of this investigation were quite rainy. According to the Hidrothermic Index of Branas, Bernon and Levadoux one can see that the years 1997 and 1998 quite exceeded the value 5100 considered as a limit from which there is a strong attack of mildew. That happened in almost the whole of the Vinhos Verdes Region, where the production of grapes fell greatly.

In tables 4 and 5 are shown the total concentrations of the volatile compounds both for the free fraction and the glycosidically bound fraction, achieved for the grape varieties Alvarinho and Loureiro, concerning the harvests of 1996, 1997 and 1998. The results are presented grouping the compounds by their chemical similarities and their biosynthetic pathways (number of compounds quantified for each group are in brackets). Concerning both the free fraction and the total concentration in each harvest, an increase was found in all the samples from the one of 1996 to the one of 1997 and from the latter to the one of 1998. Such behavior is mainly attributed to the increase of the contents of compounds in $\mathrm{C}_{6}$. Nevertheless, excluding this group of compounds, the total concentration decreases from the harvest of 1996 to the ones of 1997 and of 1998. The exceptions were found in the sample $\mathrm{L}_{\mathrm{CT}}$ of 1997 which has a greater concentration of volatiles than of 1998 and the sample $A_{S S}$ in which the contents in 1997 is inferior to that of 1996. Concerning the glycosidically fraction, the observed trend is similar to the one described for the free fraction.

After principal component analysis applied to all the compounds, it was found through the graphic representation of the first three components that all the samples, both of Alvarinho and of Loureiro, are grouped according to harvests. In all the figures $(1,2,3$ and 4 ) it is found that the component 1 (with greater \% of variance explained) enables to differentiate the harvest of 1996 from those of 1997 and 1998 and the component 2 enables to separate the harvest of 1997 from that of 1998. The component 3 itself enables, in the case of the Alvarinho variety and for the harvest of 1996, to separate the sample $\mathrm{A}_{\mathrm{AV}}$ (corresponding to grapes grown outside the recommended sub-region) from the other 
two, $A_{S S}$ and $A_{C R}$. The same happens with the Loureiro grape variety, in which the component 3 stresses the distinction between the two samples, $\mathrm{L}_{\mathrm{AV}}$ and $\mathrm{L}_{\mathrm{CT}}$, for the harvest of 1996.

Although the grapes of the samples from each grape variety are from grapevines with different rootstocks and which are grown in different places, it seems that these factors are not as influential to the biosynthesis of the volatile compounds as the natural factors.

\section{ACKNOWLEDGEMENTS}

We would like to thank the owners of the Casa da Tapada Sociedade Agrícola Lda., Solar de Serrade e Quinta da Lagoa Verde as well as the Director of the Estação Vitivinícola Amândio Galhano for all their kind cooperation in order to supply grapes for this investigation.

\section{Literature Cited}

Clímaco, P.P. 1997. Influência da cultivar e do ambiente na maturação da uva e na produtividade da videira (Vitis vinífera L.). Tese de Doutoramento. Universidade Técnica de Lisboa.

Cordonnier, A. and Bayonove, C. 1978. Les composants varietals et préfermentaires de l’arôme des vins. Parfuns, Cosmétiques, Arômes 24: 67-72.

Günata, Y.Z., Bayonove, C.L., Baumes, R.L. and Cordonnier, R.E. 1985. The aroma of grapes. I. Extraction and determination of free and glycosidically bound fractions of some aroma components. J. Chromatogr. 331: 83-90.

Oliveira, J.M. 2000a. Aromas varietais e de fermentação determinantes da tipicidade das castas Loureiro e Alvarinho. Tese de Doutoramento. Universidade do Minho

Oliveira, J.M., Maia, M.O., Baumes, R.L., Bayonove, C.L. 2000b. Free and bound aromatic components of Loureiro and Alvarinho grape varieties from the Vinhos Verdes region. Vitic. Enol. Sci. 55: 13-20

Pinho, A.J. 1993. Compêndio de Ampelologia. Figueirinhas, Porto.

Huglin, P., Schneider, C. 1998. Biologie et écologie de la vigne. $2^{\mathrm{e}}$ édition, Lavoisier, Paris.

\section{Tables}

Table 1. Codes attributed to samples

\begin{tabular}{llll}
\hline Cultivars & Code & Site & Sub-Regions \\
\hline \multirow{3}{*}{ Alvarinho } & $\mathrm{A}_{\mathrm{SS}}$ & Solar de Serrade & Monção \\
& $\mathrm{A}_{\mathrm{CR}}$ & Lagoa Verde & Monção \\
& $\mathrm{A}_{\mathrm{AV}}$ & Estação Vitivinícola Amândio Galhano & Lima \\
\hline \multirow{2}{*}{ Loureiro } & $\mathrm{L}_{\mathrm{AV}}$ & Estação Vitivinícola Amândio Galhano & Lima \\
& $\mathrm{L}_{\mathrm{CT}}$ & Casa da Tapada & Cávado \\
\hline
\end{tabular}

Table 2. Summary characteristics of soils

\begin{tabular}{|c|c|c|c|c|c|}
\hline & $\mathrm{A}_{\mathrm{SS}}$ & $\mathrm{A}_{\mathrm{CR}}$ & $\mathrm{A}_{\mathrm{AV}}$ & $\mathrm{L}_{\mathrm{AV}}$ & $\mathrm{L}_{\mathrm{CT}}$ \\
\hline Texture & Average & Fine & Average & Average & Average \\
\hline $\begin{array}{l}\text { Organic } \\
\text { matter }\end{array}$ & Very low & Average & Low & Low & Low \\
\hline Phosphorus & High & High & Very high & Average & Very high \\
\hline Potassium & Very high & Average & Very high & Average & High \\
\hline Magnesium & Low & Low & Average & Low & Very low \\
\hline Boron & Low & Low & Very low & Very low & Low \\
\hline
\end{tabular}


Table 3. Bioclimatic indexes of the samples sites

\begin{tabular}{|c|c|c|c|c|c|c|c|}
\hline \multirow[t]{2}{*}{ Index } & \multicolumn{3}{|c|}{ Monção } & \multicolumn{3}{|c|}{ Lima } & Cávado ${ }^{1}$ \\
\hline & 1996 & 1997 & 1998 & 1996 & 1997 & 1998 & 1996 \\
\hline $\begin{array}{l}\text { Winkler and } \\
\text { Amerine }\end{array}$ & 1916.6 & 2078.2 & 2031.3 & 1750.6 & 1845.4 & 1741.1 & 1574.3 \\
\hline $\begin{array}{l}\text { Heliothermic of } \\
\text { Huglin } \\
\text { Hidrothermic of }\end{array}$ & 2402.2 & 2513.9 & 2414.4 & 2066.4 & 2362.8 & 2304.2 & 2152.6 \\
\hline Selianinov & 4.3 & 3.4 & 3.1 & 4.2 & 4.8 & 4.3 & 3.9 \\
\hline $\begin{array}{l}\text { Hidrothermic of } \\
\text { Branas, Bernon } \\
\text { and Levadoux }\end{array}$ & 4271.8 & 7650.9 & 6162.0 & 4224.7 & 7979.6 & 5615.3 & 4297.5 \\
\hline
\end{tabular}




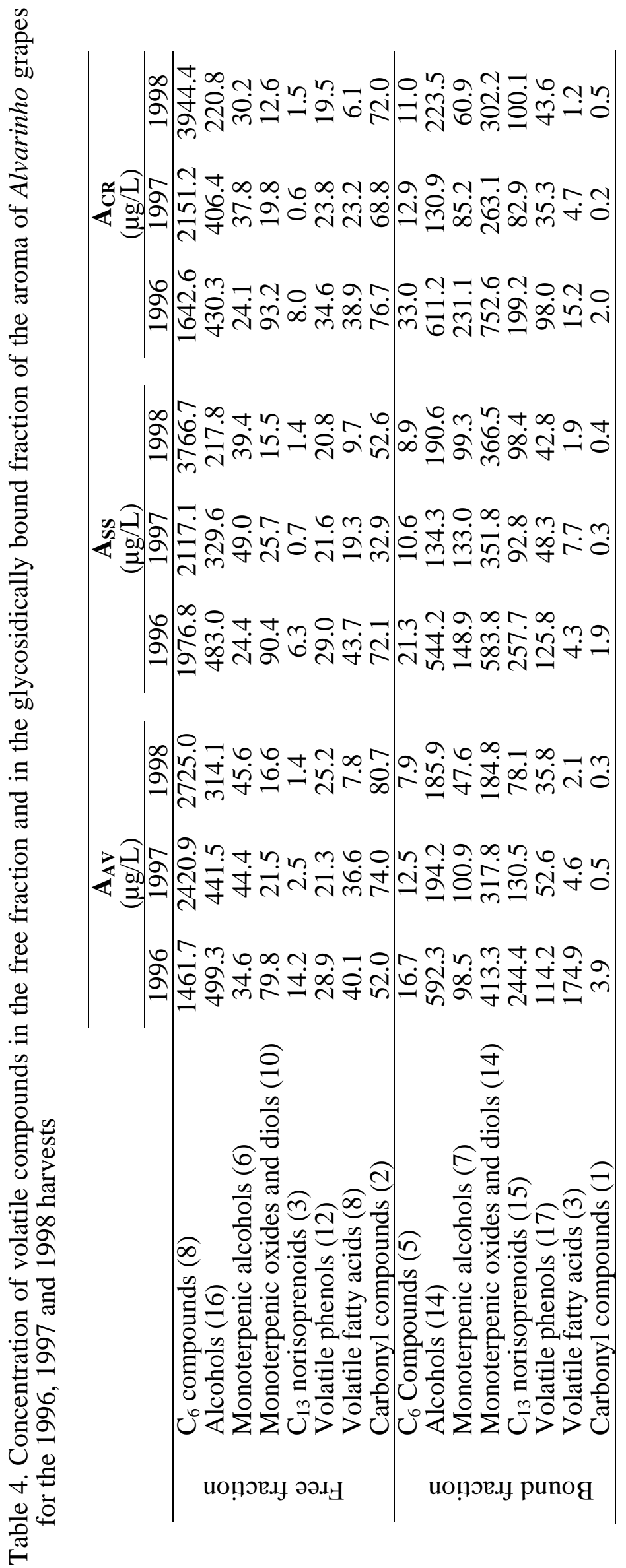


Table 5. Concentration of volatile compounds $(\mu \mathrm{g} / \mathrm{L})$ in the free fraction and in the glycosidically bound fraction of the aroma of Loureiro grapes for the 1996, 1997 and 1998 harvests

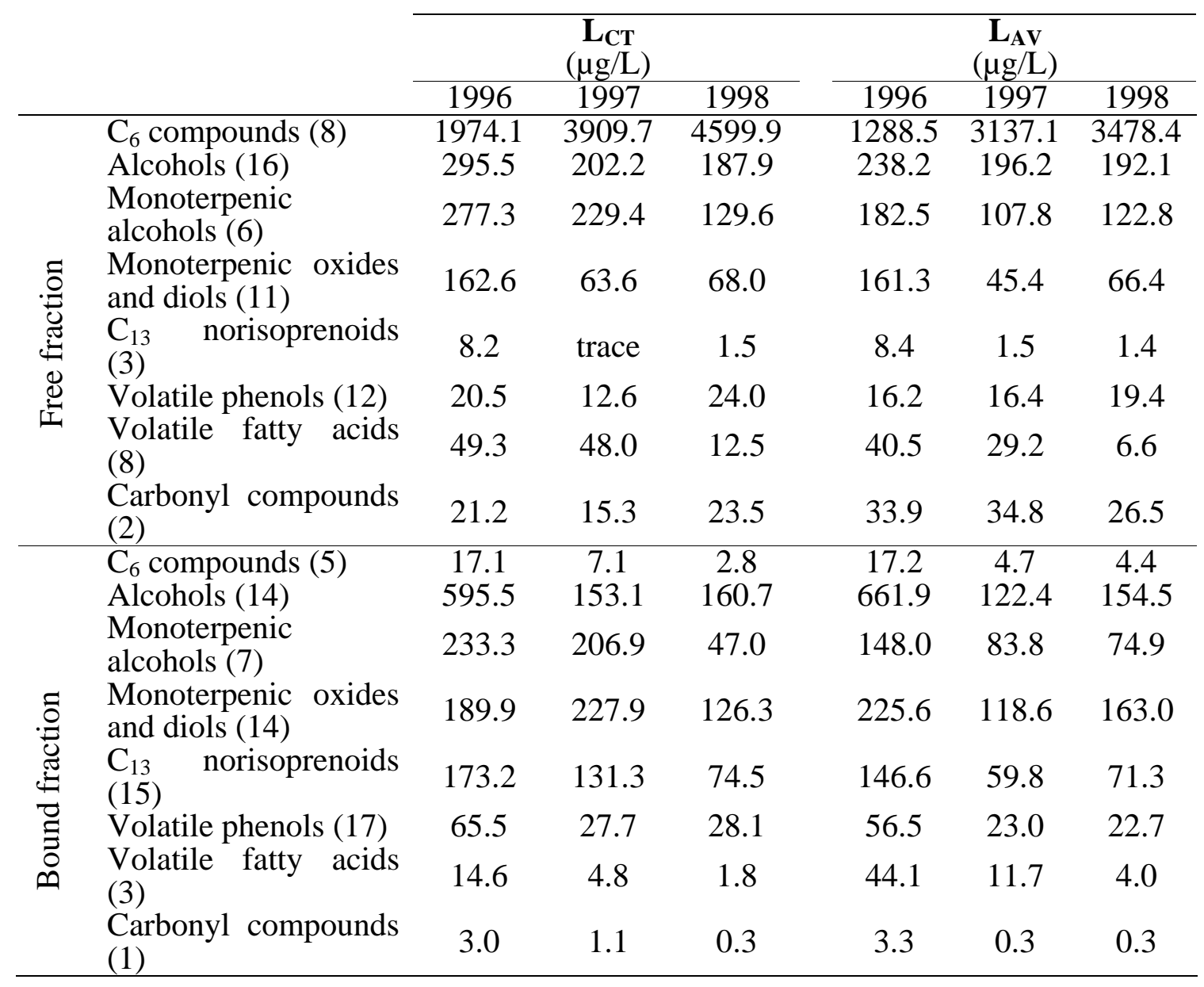




\section{Figures}
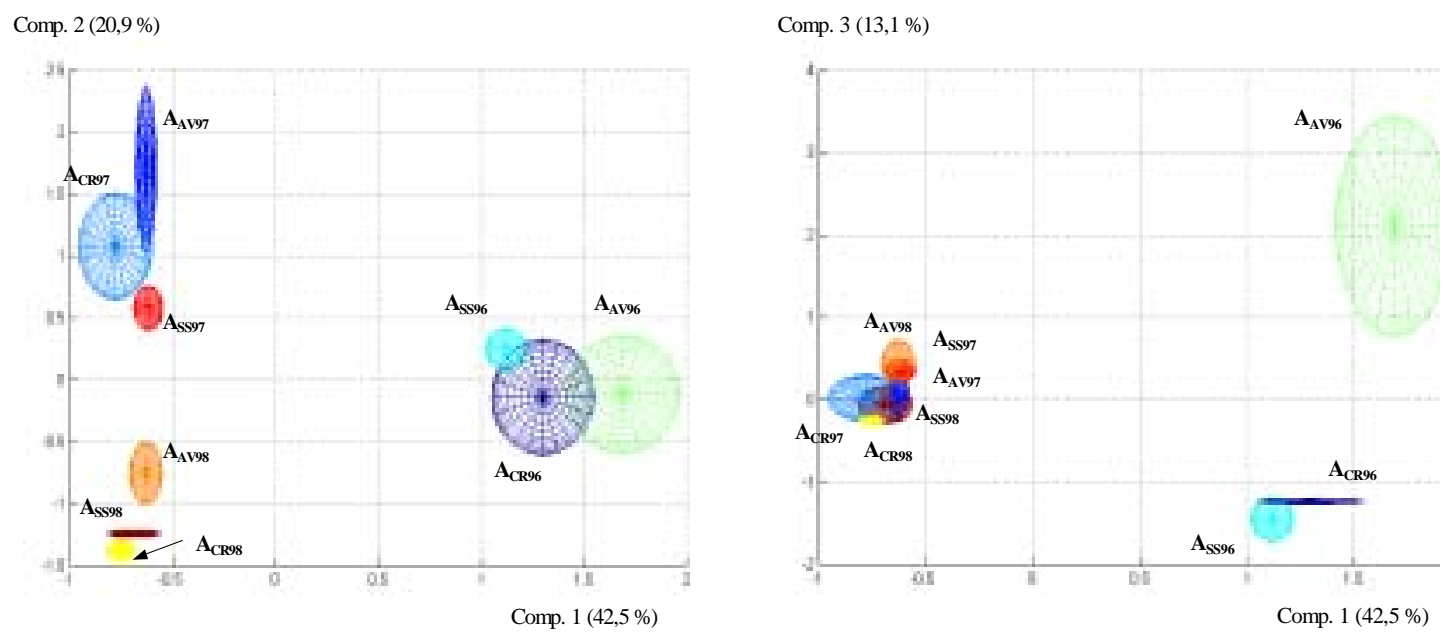

Fig. 1. Graphic representation of the three first principal components for the free fraction compounds of the aroma of the grapes from the Alvarinho variety in the harvests of 1996, 1997 and 1998. The ellipsoids represent the limit with a confidence level of $95 \%(n=3)$
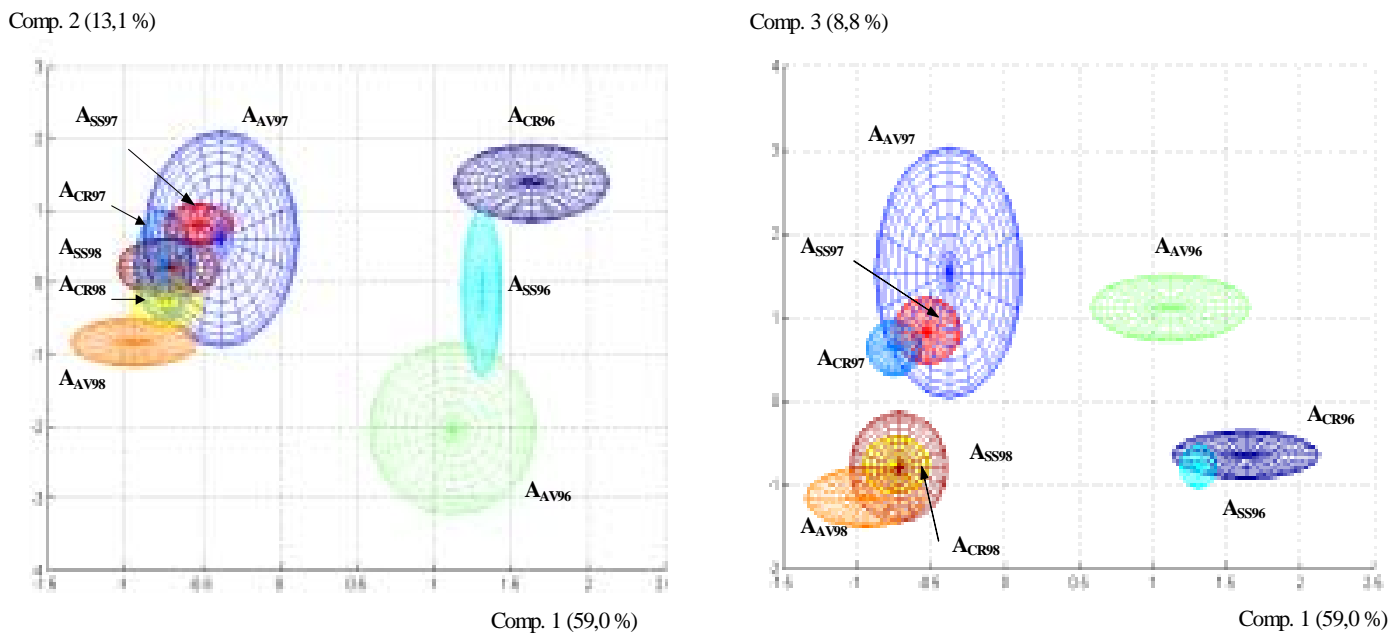

Fig. 2. Graphic representation of the three first principal components for the glycosidically bound fraction compounds of the aroma of the grapes from the Alvarinho variety in the harvests of 1996, 1997 and 1998. The ellipsoids represent the limit with a confidence level of $95 \%(n=3)$ 

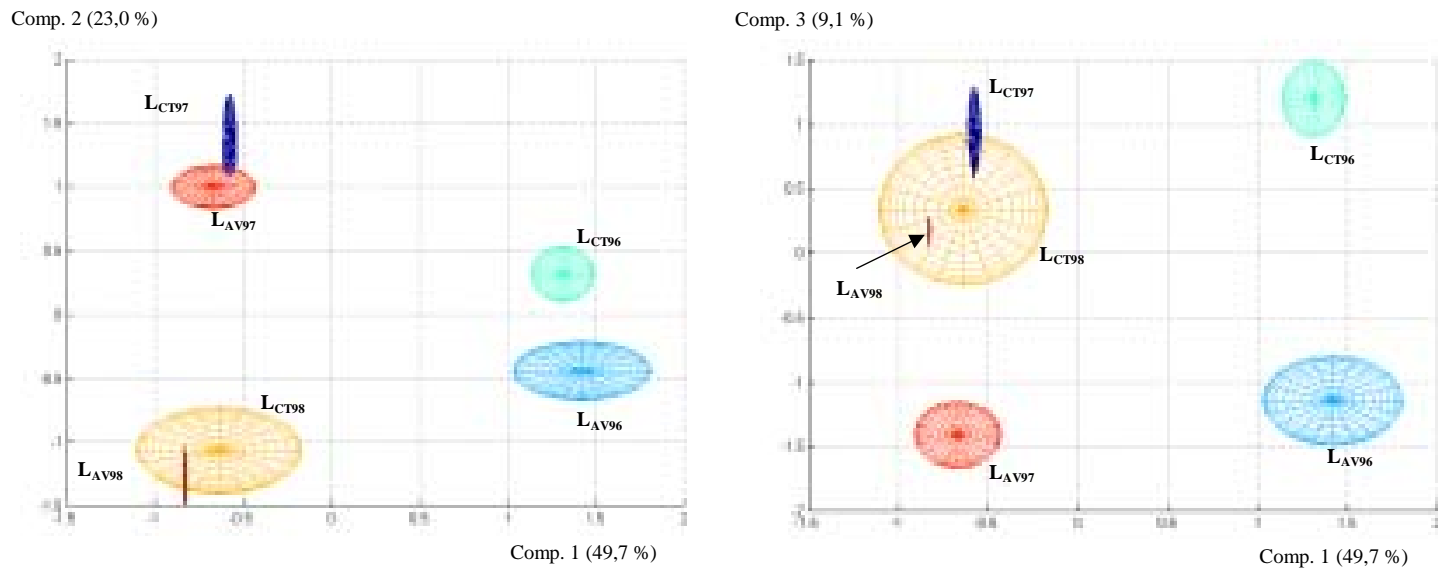

Fig. 3. Graphic representation of the three first principal components for the free fraction compounds of the aroma of the grapes from the Loureiro variety in the harvests of 1996,1997 and 1998. The ellipses represent the limit with a confidence level of $95 \%(\mathrm{n}=3)$
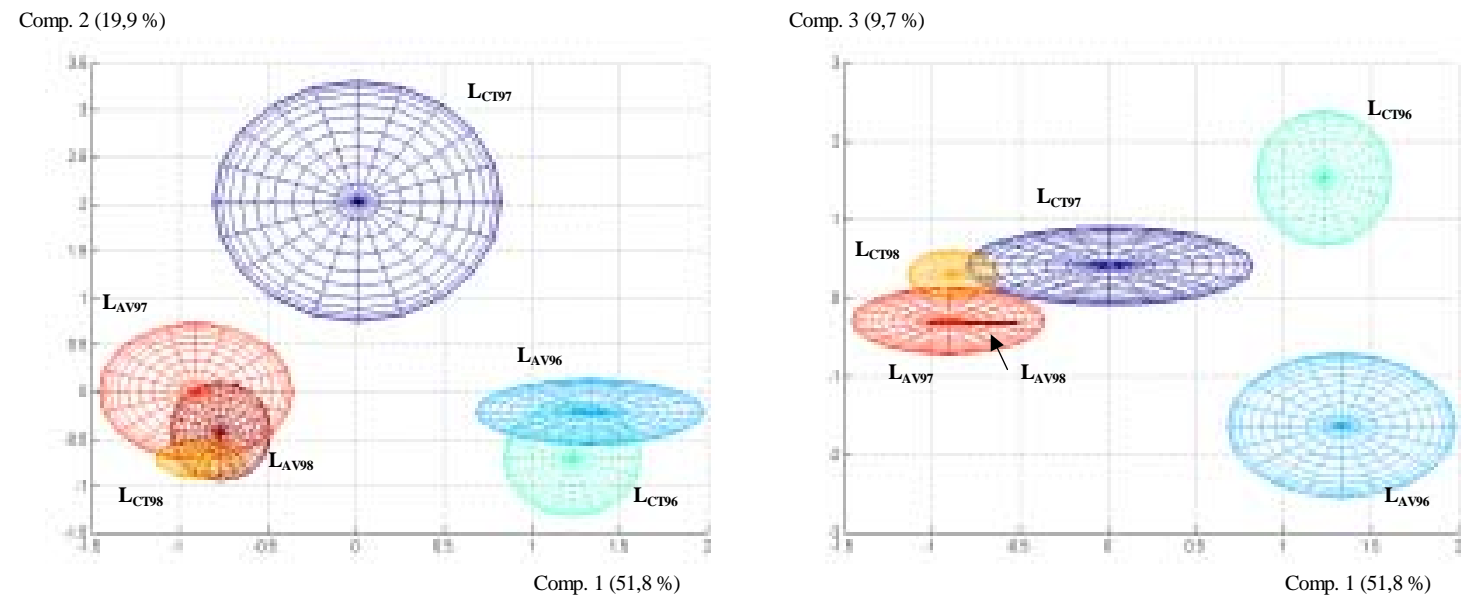

Fig. 4. Graphic representation of the three first principal components for the glycosidically bound fraction compounds of the aroma of the grapes from the Loureiro variety in the harvests of 1996, 1997 and 1998. The ellipsoids represent the limit with a confidence level of $95 \%(n=3)$ 